\title{
Tributação do capital: teoria e prática (e o caso brasileiro) *
}

\author{
Sérgio Wulff Gobetti **
}

\begin{abstract}
Resumo
Este artigo mostra como os pressupostos teóricos que deram suporte ao atual modelo de tributação da renda no Brasil (e em outros países influenciados pelo ideário liberal) estão passando por uma expressiva revisão internacional em consequência do aumento da desigualdade e do amadurecimento da teoria da tributação ótima. Essa revisão indica que tanto a progressividade quanto a tributação da renda do capital podem ser compatibilizadas num arcabouço neoclássico que busque equilibrar a busca de equidade e eficiência econômica. Em particular, conclui-se que: a isenção total de lucros e dividendos distribuídos, como ocorre no Brasil, não garante a neutralidade almejada por modelos neoclássicos fundamentados em hipóteses mais realistas sobre o comportamento dos agentes econômicos; o modelo dual de tributação, nos distintos formatos adotados pelos países nórdicos, pode servir de referência para uma reforma que propicie maiores alinhamentos de tratamento dos rendimentos do capital e, ao mesmo tempo, maior oneração das rendas extraordinárias.
\end{abstract}

Palavras-chave: Teoria da tributação ótima; Tributação do capital; Progressividade; Modelo dual nórdico.

\section{Abstract \\ Capital taxation: theory and práxis (and the Brazilian case)}

This paper shows how the theoretical assumptions that supported the current model of income taxation in Brazil (and in other countries influenced by the liberal ideology) are undergoing a significant international revision as a consequence of the increase in inequality and the maturation of the theory of optimal taxation. This review indicates that both the progressivity and the taxation of capital income can be made compatible in a neoclassical framework that seeks a balance between the search for equity and economic efficiency. In particular, it is concluded that: the total exemption of distributed profits and dividends, as takes place in Brazil, does not guarantee the neutrality sought by neoclassical models based on more realistic hypotheses about the behavior of economic agents; the dual income tax model, in the different formats adopted by the Nordic countries, can serve as a reference for a reform that will guarantee alignment of the treatment of capital incomes and, at the same time, a greater burden on extraordinary incomes.

Keywords: Theory of optimal taxation; Capital taxation; progressivity; Dual income tax.

JEL A14, B20, D63, H21, H24.

\section{Introdução}

Este artigo tem por objetivo analisar a evolução do pensamento neoclássico (e liberal) sobre tributação e seus impactos sobre a configuração dos modelos de tributação da renda do capital de distintos países capitalistas. Mais especificamente, busca-se discutir de que modo as experiências internacionais e as recentes revisões na chamada teoria da tributação ótima,

\footnotetext{
* Artigo recebido em 21 de setembro de 2017 e aprovado em 20 de outubro de 2017.

*** Pesquisador do Instituto de Pesquisa Econômica Aplicada (Ipea), Brasília, DF, Brasil. E-mail: swgobetti@gmail.com.
} 
influenciadas pela literatura empírica que trata do aumento da desigualdade e concentração de riqueza (Piketty; Saez, 2003; Atkinson; Piketty; Saez, 2009; entre outros), podem servir de referência para uma agenda de reforma tributária no Brasil.

O modelo brasileiro de tributação da renda, caracterizado pela isenção de lucros ao nível das pessoas físicas e por uma progressividade de baixo grau dos rendimentos do trabalho, foi concebido na década de 90 sob influência de propostas inovadoras e radicais - como o flat $\operatorname{tax} \mathrm{e}$ as deduções relativas ao rendimento normal do capital próprio - formuladas por acadêmicos e policymakers dos Estados Unidos e da Europa. Essas propostas almejavam resolver problemas concretos (como a falta de isonomia no tratamento das diferentes rendas do capital e os efeitos disso sobre as decisões de investimento das firmas), mas também traduziam um clamor teórico e ideológico por menor oneração do capital e dos mais ricos, baseados na suposta ineficiência econômica da tributação sobre esta elite.

Curiosamente, como será visto adiante, essa agenda de reformas nunca foi adotada na plenitude pelas grandes potências, mas foi importada pela periferia das economias capitalistas (notadamente no Leste e Sudeste europeus), mais suscetíveis talvez ao ideário liberal e às perspectivas de atrair investimentos por meio de vantagens tributárias aos grandes detentores de capital. A Estônia, por exemplo, foi o primeiro país europeu a adotar um imposto de renda linear (flat tax, FT) e a isentar dividendos distribuídos, em 1994. No mesmo ano, a Croácia implantou um sistema por meio do qual o rendimento normal do capital (mensurado pela imputação de uma taxa de juros sobre o capital próprio) também passou a estar isento de imposto (allowance for corporate equity, ACE).

O Brasil acompanhou essa "vanguarda" ao introduzir, a partir de $1^{\circ}$ de janeiro de 1996, a isenção dos lucros distribuídos e, simultaneamente, um dispositivo que ficou conhecido como juros sobre capital próprio (JCP), a versão brasileira do ACE. Antes disso, na década de 80, o país já havia reduzido a alíquota máxima do imposto de renda e submetido os dividendos à tributação exclusiva na fonte com uma alíquota linear de $15 \%$, em um formato que poderíamos comparar (imperfeitamente) ao modelo dual nórdico (dual income tax, DIT), assim denominado por distinguir o tratamento tributário das rendas do trabalho e do capital.

O foco dessa onda de mudanças era basicamente desonerar o capital, incentivar a capitalização das empresas e os investimentos e reduzir as distorções provocadas pelo modelo clássico de tributação (como a oneração da parcela da renda do capital que apenas repõe a inflação e o incentivo às empresas se financiarem via endividamento, pois assim poderiam abater os juros pagos da base de cálculo do imposto de renda). Os eventuais impactos negativos - da menor progressividade e menor tributação do capital - sobre a distribuição de renda, ou não existiriam, segundo a tese do trickle-down ${ }^{1}$, ou deveriam ser compensados por meio de transferências de renda aos mais pobres.

(1) Tese atribuída aos assessores do ex-presidente norte-americano Ronald Reagan, segundo a qual todo aumento de renda dos mais ricos respingaria para os mais pobres, justificando redução de impostos para as classes mais altas. 
Em síntese, segundo a visão dominante nos anos 90, a política tributária deveria se eximir de objetivos distributivos porque isso seria ineficiente do ponto de vista econômico. $\mathrm{O}$ gasto público, por outro lado, seria o instrumento adequado por meio do qual o governo poderia interferir na distribuição de renda, principalmente se bem focalizados, ou seja, direcionados aos realmente pobres. Assim, a autoridade fiscal deveria se preocupar em ampliar a neutralidade do sistema tributário, garantindo as condições mediante as quais a economia proporcionaria o máximo de arrecadação para atender aos objetivos alocativos e distributivos do governo.

Três décadas se passaram desde que esses mandamentos foram estabelecidos, e tanto a concentração de renda aumentou significativamente na maior parte do mundo, quanto a reflexão acadêmica avançou, produzindo uma reavaliação das teorias e práticas em termos de tributação. Alguns novos desenvolvimentos da teoria da tributação ótima, por exemplo, têm questionado a espinha dorsal dos modelos e teoremas que se popularizaram no mainstream acadêmico e que deram sustentação às proposições de menor progressividade tributária e menor tributação das rendas do capital ${ }^{2}$.

Tanto economistas da nova geração, como Piketty e Emmanuel Saez, quanto da velha guarda, como Joseph Stiglitz, Anthony Atkinson ${ }^{3}$ e Peter Diamond, têm se dedicado a demonstrar, por meio de um arcabouço estritamente neoclássico, mas baseado em hipóteses e pressupostos mais realistas, que uma política tributária ótima (no sentido de maximizar o bemestar social) pode passar por um desenho onde não só haja espaço para a progressividade tributária e a tributação do capital, como em doses superiores à que temos na atualidade.

Por outro lado, o enfraquecimento de crenças e a insolubilidade de algumas controvérsias teóricas contribuíram para o surgimento de uma abordagem mais pragmática no seio do mainstream, voltada ao desenho de medidas tributárias economicamente eficientes, politicamente factíveis e socialmente aceitáveis. Ou seja, mesmo na ausência de consensos sobre questões importantes, especialistas e policymakers buscam avançar em uma agenda de reformas na tributação para o século XXI, como demonstra o movimento de revisão liderado no Reino Unido pelo economista e prêmio Nobel James Mirrlees (Mirrlees et al., 2011) ${ }^{4}$.

No Brasil, contudo, esse debate ainda é bastante incipiente. A ilusão de que a distribuição de renda melhorava substancialmente, com base em dados de uma parte da realidade (a das pesquisas domiciliares ${ }^{5}$ ), aliado ao conservadorismo da nossa intelligentsia tributária, sufocou a maior parte das tentativas de rediscutir o modelo de tributação das rendas e dos lucros. Na academia brasileira, da mesma forma, há pouquíssima reflexão e produção

(2) É o caso, como veremos, dos teoremas de Atkinson e Stiglitz (1976) e Chamley-Judd (1986-1985).

(3) Atkinson faleceu recentemente (2017) e um de seus últimos trabalhos foi uma crítica aos modelos da teoria da tributação ótima (vide Atkinson, 2012).

(4) Mirrlees também faleceu recentemente (2018).

(5) Estudos recentes, como Medeiros et al. (2015) e Morgan (2017) mostram que as pesquisas domiciliares subestimam a renda dos mais ricos e, portanto, a queda na desigualdade de renda. 
nessa área de conhecimento, mesmo no âmbito do mainstream, o que criou um enorme distanciamento e alienação em relação ao debate teórico internacional ${ }^{6}$.

A própria retomada do tema no Brasil continua muito focalizada nas distorções que nosso sistema de tributação induz, como a transfiguração da renda do trabalho em renda do capital (a chamada pejotização), que é um problema seríssimo, mas não é o único. A baixa tributação das altas rendas, sejam elas do trabalho ou do capital, contribui decisivamente para que o Brasil possua o mais elevado índice de concentração de renda no topo da pirâmide entre todos os países com dados disponíveis (Gobetti; Orair, 2017). A menos que não se entenda que esse seja um problema, é preciso pensar em quais instrumentos tributários poderiam ajudar a enfrentá-lo, pois as ações pelo lado do gasto são de pouca eficácia nesse caso e principalmente num contexto de crise fiscal, no qual o governo tem limitadas possibilidades de ampliar os programas de transferência de renda.

Nesse sentido, este artigo visa contribuir para que se possa repensar nosso modelo de tributação da renda e dos lucros com um duplo olhar, tanto para seus impactos sobre a eficiência, quanto sobre a equidade e o bem-estar social. A pergunta que se coloca é: podemos introduzir mudanças no sistema tributário que melhorem sua neutralidade, tenham os menores efeitos inibidores possíveis (ou até mesmo estimulem) o crescimento econômico, reduzam a concentração de renda e sejam socialmente benéficas?

\section{Dos clássicos à teoria da tributação ótima: o conflito entre equidade e eficiência}

O princípio segundo o qual os indivíduos devem contribuir para o governo pagando impostos de acordo com sua capacidade contributiva tem longa data e era defendido como fundamental por alguns pensadores clássicos, como Adam $S_{\text {Smith }}^{7}$. O modo como esse princípio é interpretado e, principalmente, o modo como os economistas entendem que ele deva ser aplicado, contudo, tem variado ao longo do tempo ${ }^{8}$. Para Mill (1849), por exemplo, a premissa de que todos indivíduos sejam tratados como iguais perante a lei exigiria que se impusesse um "sacrifício igual" a todos, o que poderia justificar a aplicação de um imposto proporcional e não progressivo. Contudo, segundo argumentação dos economistas da escola marginalista, o fato de a utilidade marginal decrescer com o aumento da renda (uma unidade monetária adicional tem mais utilidade para um pobre do que para um rico) implicaria a necessidade de um tributo progressivo para igualar o sacrifício em termos absolutos.

De todo modo, por razões de economia política que extrapolam a polêmica filosófica, como mostra Piketty (2014), o princípio de que os ricos devem pagar proporcionalmente mais

(6) Uma rara e positiva exceção é o estudo de Almeida e Paes (2013), que analisa a influência dos juros sobre capital próprio e das taxas de juros brasileiras sobre a neutralidade tributária.

(7) Em A Riqueza das Nações, de 1776, Smith recomenda: "Os súditos de cada Estado devem contribuir o máximo possível para a manutenção do governo, em proporção a suas respectivas capacidades, isto é, em proporção ao rendimento de que cada um desfruta, sob a proteção do Estado."

(8) Ver Musgrave (1994) para um ótimo apanhado de como essa visão evoluiu entre os clássicos e neoclássicos. 
impostos do que os pobres se difundiu e consolidou nas sociedades ocidentais ao longo do século XX, refletindo-se em estruturas de tributação extremamente progressivas e que não faziam distinção entre as rendas do trabalho e do capital ${ }^{9}$.

A partir da década de 70, entretanto, esse modelo clássico (e conceito amplo de renda) passou a ser questionado em duas frentes: uma política, capitaneada pelos seguidores de Ronald Reagan e Margareth Tatcher, incluindo aí os economistas encarregados de dar uma justificativa para a revolução liberal-conservadora a partir de teses de elevada carga ideológica ${ }^{10}$, e outra de natureza mais acadêmica, baseada na chamada teoria da tributação ótima, que convergia para algumas proposições de orientação liberal, mas com a sofisticação de modelos microfundamentados que pretendiam mimetizar o comportamento dos agentes econômicos em diferentes arranjos tributários e derivar o resultado disso sobre o equilíbrio econômico e sobre o bem-estar social.

Um elemento-chave desse arcabouço teórico de vertente neoclássica é a presunção de que existe sempre um trade-off entre equidade e eficiência, ou seja, de que medidas tributárias que visem a redistribuição de renda (como a tributação progressiva da renda do trabalho ou do capital) geram distorções e apresentam custo econômico, principalmente por desestimular os indivíduos mais capazes a trabalhar, poupar e investir. Além disso, segundo muitos adeptos dessa escola, a tributação da poupança (ao menos do retorno normal da poupança, como explicaremos adiante) teria a propriedade de distorcer as decisões intertemporais de consumo e trabalho das pessoas, penalizando relativamente mais o consumo futuro do que o presente.

Dessa forma, o sistema tributário deveria ser desenhado de modo a ser o mais neutro possível, ou seja, produzir o mínimo possível de distorções econômicas e comportamentais e maximizar o bem-estar da sociedade, ponderando tanto os ganhos derivados de uma melhor distribuição de renda quanto as perdas decorrentes do impacto negativo dos impostos. Nesse sentido, a teoria da tributação ótima é uma teoria normativa de second best, estruturada sobre modelos com elevado grau de abstração, que, nas suas versões mais puras, assumem agentes econômicos racionais e perfeitamente informados, que conseguem prever com certa precisão sua renda futura e com grande flexibilidade para tomar decisões alocativas de quantas horas vão trabalhar, quantas horas vão dedicar ao lazer e como distribuirão seu consumo ao longo da vida de acordo com as características e mudanças dos impostos.

A partir desse tipo de hipóteses e de uma abordagem utilitarista, economistas neoclássicos passaram a derivar na década de 70 e 80 alguns teoremas que se tornaram muito influentes na academia e que pareciam justificar movimentos em duas direções: a redução da

(9) Esse modelo amplo de tributação da renda (comprehensive income tax, CIT) era questionado por Kaldor (1955) $\mathrm{e}$ outros economistas que entendiam que o consumo seria a melhor forma de mensurar a capacidade contributiva e de que a tributação da renda seria inibidora da poupança. Contudo, o princípio da progressividade (de que os ricos devem pagar proporcionalmente mais impostos) não era mais contestado como no final do século XIX.

(10) Como a tese de que a redução de impostos para os mais ricos estimularia os investimentos e o empreendedorismo, gerando ganhos para toda a sociedade (trickle-down). 
progressividade ou adoção de um imposto de renda linear, como analisado por Mirrlees (1971), e a redução ou eliminação da tributação sobre as rendas do capital, como implicitamente sugerido no artigo seminal de Atkinson e Stiglitz (1976) e reforçado posteriormente por Judd (1985) e Chamley (1986) ${ }^{11}$.

A ideia de restringir a progressividade se baseia em duas premissas comuns em modelos microeconômicos neoclássicos: 1) a de que os salários refletem exatamente a produtividade marginal do trabalho; 2) a de que a oferta de trabalho (medida em horas) é bastante elástica entre os indivíduos mais capazes, ou seja, responde sensivelmente às variações na renda líquida pós-tributação. Dessa forma, alíquotas marginais elevadas e crescentes tenderiam a desincentivar justamente os indivíduos mais produtivos, resultando em uma perda econômica para o conjunto da sociedade e, portanto, em menos receita para o governo utilizar em políticas distributivas.

Contudo, Mirrlees (1971, p. 207) chega a se declarar um tanto surpreso com o fato de suas derivações ótimas apontarem para o extremo de um imposto de renda quase-linear. E recomenda cautela na aplicação de suas especulações teóricas, sugerindo a necessidade de mais estudos, principalmente em função das hipóteses do modelo.

Being aware that many of the arguments used to argue in favour of low marginal tax rates for the rich are, at best, premised on the odd assumption that any means of raising the national income is good, even if it diverts part of that income from poor to rich, I must confess that I had expected the rigorous analysis of income-taxation in the utilitarian manner to provide an argument for high tax rates. It has not done so. (...) I would also hesitate to apply the conclusions regarding individuals of high skill: for many of them, their work is, up to a point, quite attractive, and the supply of their labour may be rather inelastic (apart from the possibilities of migration).

Apesar das ressalvas do autor e da vasta e (até hoje) inconclusiva literatura internacional dedicada a testar analítica e empiricamente a estrutura ótima de um imposto de renda (Kaplow, 2008), a comunidade econômica foi convencida desde os anos 80 de que a progressividade tributária seria um instrumento ineficiente de distribuição de renda.

Paralelamente, o postulado teórico de que a alíquota ótima sobre a renda do capital seria zero (com base em modelos neoclássicos) também reforçou as proposições da corrente supply-side e se tornou muito influente na academia, a ponto de Robert Lucas (1990, p. 314) considerá-lo "o maior almoço genuinamente livre" oferecido pela ciência econômica contemporânea.

Under what I view as conservative assumptions, I estimated that eliminating capital income taxation would increase capital stock by about 35 percent. (...) Translated into an effect on welfare, I estimated the overall gain (...) to be around one percent of

(11) Recentemente, Stiglitz (2017) revisa o teorema de 1976 argumentando que muitos economistas do mainstream, como Gregory Mankiw e Robert Lucas, não compreenderam as limitações do modelo adotado e se utilizaram inapropriadamente de suas conclusões para defender a não tributação do capital. 
Tributação do capital: teoria e prática (e o caso brasileiro)

consumption, or perhaps slightly less. Now one percent of U.S. consumption is about $\$ 30$ billion, and we are discussing a flow starting at this level and growing at 3 percent per year in perpetuity. It is about twice the welfare gain that I have elsewhere estimated would result from eliminating a 10 percent inflation, and something like 20 times the gain from eliminating post-war sized business fluctuations. It is about 10 times the gain Arnold Harberger (1954) once estimated from eliminating all product-market monopolies in the U.S. (...) The supply-side economists, if that is the right term for those whose research I have been discussing, have delivered the largest genuinely free lunch I have seen in 25 years in this business, and I believe we would have a better society if we followed their advice.

É curioso que, a despeito desse enorme apelo teórico e ideológico, nem os Estados Unidos nem outro grande país capitalista tenha adotado ao pé da letra, até hoje, as posições extremas derivadas desses modelos de tributação ótima, embora a agenda supply-side tenha influenciado a redução acentuada das alíquotas máximas de imposto de renda e a criação de mecanismos para atenuar a dupla tributação do lucro. Como já mencionado, os países que mais se aproximaram de eliminar a progressividade e a tributação do capital foram as pequenas nações do Leste Europeu, durante a década de 90, após a dissolução da União Soviética, mas mesmo nesses países persiste algum nível de tributação do lucro.

Essa distância entre a prescrição da teoria ótima e a prática, segundo Kaplow (2008, p. 79), poderia se explicar pela economia política, pelas preferências do eleitor mediano em torno dos princípios da progressividade e justiça tributária. Contudo, como bem observa Sheffrin (1994), a percepção de "justiça" da opinião pública é volátil, imperfeitamente construída ${ }^{12}$ e suscetível à influência de ideologias e lobbies, de modo que parece difícil atribuir apenas às preferências do eleitor mediano a não adoção de determinadas "fórmulas ótimas" durante um período de hegemonia liberal-conservadora, como foram os anos 80 e 90.

Talvez uma explicação alternativa mais simples e convincente seja a falta de robustez da modelagem teórica, sua falta de fundamentação no mundo real, conforme argumentam Piketty e Saez (2012, p. 1), dois economistas relativamente jovens que têm contribuído para um processo de autocrítica e aprimoramento da teoria da tributação ótima. O que o próprio Stiglitz tem reconhecido ao abordar o tema da tributação. "By clarifying the conditions under which you wouldn't tax capital," disse ele a Bloomberg, "it helps clarify the reasons why you would" (Coy, 2014).

O principal argumento para não tributar as rendas do capital (no sentido amplo, não apenas os lucros), do ponto de vista da teoria neoclássica, é evitar em última instância uma distorção intertemporal nas decisões sobre poupança, ou seja, sobre quanto consumir hoje ou no futuro, devido à redução no valor presente do consumo futuro produzida pelo imposto que

\footnotetext{
(12) O autor mostra, por meio de pesquisas qualitativas, como a opinião pública tem um conhecimento limitado do código tributário e tende a ver diferentes aspectos da tributação com compartimentos mentais separados, o que explica certa contradição nos julgamentos e na percepção de justiça.
} 
incidiria na remuneração do capital ${ }^{13}$. Existem outros argumentos para não tributar a renda do capital exatamente como a renda do trabalho, ou para tratar a tributação do lucro na pessoa jurídica e na pessoa física de modo integrado, mas o argumento para simplesmente não tributar a renda do capital decorre de seu efeito de desincentivo à poupança, como aliás já argumentava Kaldor (1955) ao propor um imposto progressivo sobre o consumo (expenditure tax) em alternativa a um imposto sobre a renda ${ }^{14}$.

No caso dos teoremas originais de tributação ótima, entretanto, apenas a renda do capital deveria ter alíquota zero, mas as rendas do trabalho continuariam sendo tributadas, inclusive pelos fins distributivos da função de bem estar social. Basicamente, a intuição por trás do modelo é a seguinte: uma vez que a renda original obtida dos salários já é tributada, não haveria razão para tributar uma segunda vez o retorno da parcela poupada, pois isso - repetindo - criaria um incentivo para consumir mais renda no presente. Note-se que, embora sejam admitidas diferenças de renda e consumo entre os agentes econômicos, basicamente todos eles trabalham e poupam apenas com o objetivo de obter renda para o consumo, sendo negligenciado em muitos desses modelos a existência de outras motivações para poupar ou de indivíduos que vivem de herança.

A falta de realismo nessas hipóteses é o núcleo da crítica que a proposição de não tributar a renda do capital passou a sofrer no interior da própria escola de tributação ótima, como mostra o seguinte comentário de Banks e Diamond (2008, p. 2), dois economistas do grupo reunido por James Mirrlees para produzir um diagnóstico e uma proposta de reforma do sistema tributário inglês:

We argue that a widely recognized result of the optimal tax literature - that capital income should not be taxed, in order that individual's choices regarding saving for future consumption are left undistorted relative to the choices over immediate consumption arises from considerations of individual behaviour and the nature of economic environments that are too restrictive when viewed in the context of both theoretical findings in richer models and the available empirical econometric evidence. Hence such a result should be considered not robust enough for applied policy purposes and there should be some role for including capital income as a component of the tax base.

De acordo com estes autores, existe uma correlação positiva entre a capacidade dos indivíduos obterem renda e sua propensão a suavizar o consumo ao longo da vida por meio de

(13) Note-se, antes de mais nada, que o valor presente é calculado descontando o consumo futuro pela própria taxa de juros que remunera a poupança, de modo que necessariamente o valor presente de consumir no futuro (quando houver tributação do rendimento da poupança) será menor do que o valor presente de consumir no presente. Isso ocorrerá mesmo que o retorno líquido da poupança (pós-tributação) seja maior do que a inflação, em cujo caso o consumo futuro seria, em termos reais, maior do que o consumo presente.

(14) Kaldor sustentava que um expenditure tax seria superior a um imposto sobre a renda tanto porque o consumo seria um melhor indicador da capacidade contributiva, quanto porque não incidiria sobre a parcela poupada da renda e, dessa forma, poderia favorecer o investimento desde que viabilizasse os corretos canais de financiamento de longo prazo. Mas sua proposta de tributar o consumo implicava adotar um mecanismo de progressividade, taxando os valores consumidos por cada indivíduo de forma proporcionalmente crescente. 
poupança, bem como sua habilidade de prever e lidar com as incertezas sobre a renda futura. Ou seja, os indivíduos mais capazes tenderiam a poupar mais do que o necessário por razões precaucionais e isso poderia resultar em menos trabalho no futuro. Nessas circunstâncias, a tributação da poupança passaria a ser um instrumento ótimo, tanto por atingir os indivíduos mais capazes e induzi-los a poupar menos hoje (e evitar que trabalhem menos amanhã), como subsidiar (com menos imposto sobre a renda do trabalho) aqueles que não tem condições de suavizar o consumo (na presença de restrição à liquidez).

Behavioral analysis of saving behavior is highly relevant for the choice of tax base. It is also important for evaluating the role of mandatory programs that require contributions when working and provide benefits when retired. And these two institutions need to be considered together. A key tax design issue is how to combine concern that some fraction of the population saves too little for an adequate replacement rate in retirement while another fraction saves too much, resulting in their retiring too soon from the perspective of social welfare optimization (Banks; Diamond, 2008, p. 59).

A tributação do capital também cumpre um papel fundamental, segundo Piketty e Saez (2012), num mundo em que a riqueza é extremamente concentrada e no qual a desigualdade emerge de duas dimensões - as diferenças de renda do trabalho devido a diferentes capacidades e, principalmente, as diferenças de herança -, sendo que os indivíduos que mais recebem herança nem sempre são aqueles que mais recebem salário. Desse modo, não basta tributar progressivamente a renda do trabalho para reduzir as desigualdades e proporcionar os incentivos mais desejáveis.

É importante observar que nenhuma das visões alternativas apresentadas até aqui chegam a propor uma ruptura com o arcabouço analítico da teoria da tributação ótima; ao contrário, buscam enriquecer os modelos de inspiração neoclássica com a incorporação de hipóteses mais realistas e de contribuições de outras áreas, como a economia comportamental e os estudos sobre a desigualdade, de modo a justificar a adoção de arranjos tributários progressivos, bem como a tributação da renda do capital, da herança e do patrimônio.

As pesquisas focadas em micro-dados das declarações de imposto de renda, por exemplo, têm servido não apenas para estudar o fenômeno da crescente desigualdade, como também para estimar parâmetros e modelar funções de distribuição essenciais na derivação de alíquotas e estruturas ótimas de tributação. Diamond e Saez (2011) demonstram, com base nesse tipo de enfoque, que a alíquota máxima de imposto de renda vigente nos Estados Unidos, de 42,5\% na ocasião, seria ótima apenas sob a hipótese de uma elasticidade da oferta de trabalho extremamente elevada, igual a 0,9 , muito maior do que tem sido estimado pela literatura empírica, mesmo quando consideradas as possibilidades de evasão (ou migração) entre indivíduos de altíssima renda.

Com parâmetros mais realistas ${ }^{15}$, a alíquota ótima encontrada para o topo varia entre $54 \%$ e $73 \%$. Ou seja, estes seriam os limites superiores (com ou sem evasão) a partir dos quais

(15) As elasticidades consideradas foram de 0,25 ou 0,57 no caso de possibilidade de evasão. 
a imposição de alíquotas marginais mais altas passaria a produzir uma tal reação dos contribuintes (redução de oferta de trabalho e/ou evasão) que a receita obtida pelo governo passaria a cair, verificando-se o famoso efeito da curva de Laffer.

No Brasil, é claro, estamos bem abaixo desse limite superior, mas os regimes especiais de tributação das pequenas empresas (lucro presumido e Simples) oferecem uma oportunidade ímpar de transfiguração da renda do trabalho em renda do capital, exigindo que toda e qualquer medida de ajuste nas alíquotas do imposto de renda das pessoas físicas seja casada com modificações na forma de tributar os dividendos distribuídos a acionistas, atualmente isentos tema ao qual retornaremos na última seção.

A existência de uma fronteira opaca entre as rendas do trabalho e as rendas do capital, pelo menos para aquela parte da população que trabalha de forma autônoma ou tem a possibilidade de escolher a forma como prestará serviço (como pessoa física ou jurídica), é uma das razões elencadas por Piketty, Saez e Zucman (2013) para não só tributar a renda do capital, como tributá-la conjuntamente com as rendas do trabalho, submetendo a soma de todas elas à escala progressiva de alíquotas (comprehensive income tax, CIT), como ainda hoje ocorre em muitos países desenvolvidos.

Em resumo, os autores defendem a rationale de um imposto de renda amplo e progressivo complementado por um imposto também progressivo sobre a riqueza (que seja cobrado anualmente) e finalmente por um imposto progressivo sobre a herança.

The very notions of income and consumption flows are difficult to define and measure for top wealth holders. Therefore the proper way to tax billionaires is a progressive wealth tax. Finally, there are strong meritocratic reasons why we should tax inherited wealth more than earned income or self-made wealth (Ibid, p. 1).

De modo semelhante, Stiglitz (2017, p. 43) também defende a tributação progressiva da renda do capital, argumentando que a crescente desigualdade tem efeitos adversos tanto sobre o bem-estar social quanto sobre a própria produtividade da economia. Essa visão, evidentemente, está longe de representar um consenso na escola da tributação ótima. À parte dos economistas que ainda hoje veem a tributação do capital e da renda como algo extremamente negativo que deveria ser evitado, há um amplo espectro de neoclássicos que admitem tributar o estoque de riqueza e, em alguma medida, o fluxo de renda proporcionado por ele, mas não conjuntamente, nem progressivamente como as rendas do trabalho. O modelo dual, concebido e implementado pelos países nórdicos, por exemplo, combina a tributação progressiva da renda do trabalho com a tributação linear sobre a renda do capital, e é complementado por um imposto sobre o estoque de riqueza.

A otimalidade do modelo dual, segundo Nielsen e Sorensen (1997), reside no fato de que, justamente ao diferenciar a tributação das rendas do capital e do trabalho, ele possibilitaria equalizar o tratamento dispensado ao capital humano e ao não-humano. $\mathrm{O}$ argumento - de que a diferenciação produz equalização - parece não ter sentido, mas se desenvolve a partir de um raciocínio semelhante àquele originalmente aplicado pela teoria da tributação ótima ao tratar 
da distorção que um imposto sobre a poupança causaria sobre a decisão intertemporal de consumo: o investimento em capital humano, traduzido em mais tempo presente dedicado ao estudo, proporciona um retorno que será tributado apenas no futuro, quando a renda adicional for auferida, enquanto o investimento em ativos financeiros, com a renda poupada proveniente do trabalho atual, têm seu retorno tributado desde o princípio.

Nesse sentido, a maior tributação relativa da renda do trabalho (em comparação com a renda do capital) serviria para reduzir ou eliminar o viés em favor do capital humano ${ }^{16}$. Outra razão de ordem mais prática que influenciou a adoção do modelo dual, segundo Sorensen (2009), foi promover uma espécie de compensação pelo fato de a tributação incidir sobre todo o rendimento nominal do capital, incluindo a correção monetária pela erosão do valor real dos ativos. Em tese, essa correção também poderia ter sido feita por dentro do modelo amplo de tributação da renda, incluindo algum mecanismo de expurgo do efeito inflacionário presente nas rendas do capital, mas raros países fazem isso.

De qualquer forma, segundo a visão talvez majoritária da escola de tributação ótima, sintetizada por Mirrlees et al. (2011), a compensação pela inflação seria insuficiente para alcançar a neutralidade tão almejada pela teoria da tributação ótima. Além da neutralidade no que se refere às decisões intertemporais, que já abordamos anteriormente, há um outro tipo de neutralidade mais importante, relacionada à escolha individual de onde alocar a poupança e à decisão das empresas de como financiar seus investimentos.

Enquanto o primeiro tipo de neutralidade é bastante discutível e preocupa mais os acadêmicos, o segundo tipo tem despertado crescente atenção dos economistas envolvidos no debate de reformas tributárias, principalmente no contexto de maior mobilidade internacional de capitais e crescente variedade de instrumentos financeiros - às vezes criados com o simples objetivo de dissimular a verdadeira natureza de uma renda de capital. Dessa forma, toda e qualquer lacuna ou diferencial de tributação verificado no sistema, ou entre países, tende a ser explorado pelos agentes econômicos, principalmente os mais ricos, aqueles que idealmente a "política ótima" pretende atingir para desconcentrar renda e ampliar o bem-estar social.

É nesse ponto que os neoclássicos voltam a se dividir. Enquanto Stiglitz (2015) e Piketty, Saez e Zucman (2013) defendem uma coordenação internacional das autoridades para enfrentar a situação e conseguir taxar os mais ricos, outros economistas apostam justamente na maior competição tributária para definitivamente erradicar toda e qualquer forma de tributação direta da renda do capital (tanto na pessoa física, quanto jurídica) e substitui-lo por um tipo de imposto sobre o valor adicionado (após deduzirem-se os custos salariais) ou sobre o fluxo de caixa - único com a propriedade da quase-neutralidade, segundo argumentam.

(16) Essa assertiva depende, entretanto, de que a educação seja gratuita, como via de regra ocorre nos países nórdicos, ou que os custos suportados por cada indivíduo sejam totalmente dedutíveis do imposto de renda; do contrário, o custo de oportunidade de estudar em vez de trabalhar (abdicar de renda presente para buscar maior renda futura) pode se tornar muito alto e a racionalidade de um atenuante tributário para as rendas do capital pode deixar de existir (Nielsen; Sorensen, 1997, p. 322). 
A neutralidade existiria nesse caso porque um imposto que funcione na base do fluxo de caixa utiliza uma taxa de desconto, em geral igual à taxa normal de juros, que é aplicada para trazer a valor presente todas as "entradas" e "saídas" da conta da pessoa ou da empresa, de modo a não interferir nas decisões intertemporais e alocativas. No caso das empresas, por exemplo, um imposto sobre o fluxo de caixa elimina a vantagem hoje existente em financiar investimentos via empréstimos, pois o gasto com juros deixa de ser deduzido - ao invés disso, a empresa deduz todos os investimentos, assim como registra o empréstimo recebido na receita. Do ponto de vista dos investidores, essa sistemática também elimina o estímulo para que a empresa retenha lucros e os acionistas adiem a venda de ações para não realizar o ganho de capital (incorporado na valorização dos ativos) e não pagar tributos.

Contudo, um imposto sobre o fluxo de caixa, em perspectiva individual, oferece um estímulo à acumulação indefinida de capital, uma vez que a renda somente será tributada quando consumida e quando exceder, em taxa de rentabilidade, a taxa de desconto. ${ }^{17}$ Note que o ato e o desejo de "acumular por acumular" é estranho em geral aos modelos neoclássicos, mas esse problema poderia em tese ser resolvido por um imposto sobre herança, desde que não existissem estratégias de planejamento sucessório que objetivam justamente driblar esse tipo de tributação, o que torna tão complexo o desenho de um sistema tributário ótimo.

Além disso, diferente da concepção de Kaldor (1955), o novo expenditure tax neoclássico não é idealizado para ser progressivo, o que denota a crença predominante no mainstream de que impostos não são um bom instrumento de distribuição de renda.

Independentemente dessas convicções, o fato é que a desigualdade e a concentração de renda cresceram sensivelmente nas últimas décadas, e a teoria da tributação ótima não poderia permanecer imune a esse choque de realidade, como reconhecem Mirrlees et al. (2011, p. 8):

Income and wealth are much less equally distributed across the population than they were 30 years ago. It is rarely understood quite how dramatic that change has been, nor how important it is for the formulation of public policy in general and tax policy in particular.

Tensionado pelo teórico conflito entre equidade e eficiência e pelas visões antagônicas no seio do mainstream, a Revisão de Mirrlees representa a busca de um ponto de equilíbrio, um acordo em torno de diretrizes para uma reforma do sistema tributário. O documento, formulado por James Mirrlees com a colaboração de outros economistas britânicos do Instituto para Estudos Fiscais e precedido de estudos específicos realizados por especialistas, como é o caso do texto de Banks e Diamond (2008), é a melhor e mais completa síntese do pensamento liberal contemporâneo sobre tributação e guia indispensável para qualquer discussão de qualidade sobre o tema na atualidade.

(17) Se o ativo não se valorizar mais do que a taxa de desconto, a renda é isenta, pois os fluxos de crédito e débito serão iguais e de sinais trocados. 
Retornando ao problema da neutralidade, por exemplo, Mirrlees et al. (2011) propõem, como alternativa equivalente ao expenditure tax, um modelo de tributação da renda do capital que isente o rendimento normal do capital. Ou seja, sugere-se que apenas as rendas econômicas ou os rendimentos extraordinários, acima de uma taxa normal de juros, sejam tributados e que esse esquema seja complementado por um imposto sobre herança para atingir as rendas não acumuladas por esforço próprio. Como veremos na próxima seção, a proposta se assemelha ao modelo dual norueguês para as pessoas físicas e ao modelo belga de allowance for corporete equity para as pessoas jurídicas, sendo facilmente adaptável à estrutura dos impostos de renda existentes na atualidade.

Em certa parte do capítulo 13, entretanto, a Revisão admite que podem existir razões para também tributar parcialmente o rendimento normal do capital, talvez em deferência a Peter Diamond, que defende essa ideia e colaborou ativamente com Mirrlees no início de suas pesquisas sobre a tributação ótima. Lembremos que os estudos de economia comportamental referidos anteriormente têm mostrado, com base em evidências da psicologia experimental, que os indivíduos com maior habilidade cognitiva têm maior paciência e que isso se traduz em maior propensão a poupar. Dessa forma, o nível de poupança seria um indicador complementar de capacidade contributiva, justificando-se sua tributação do ponto de vista ótimo, mesmo que às custas de uma eventual distorção contra o consumo futuro ${ }^{18}$.

Por outro lado, a tributação de parte do rendimento normal da poupança também é justificada em função da necessidade de não desestimular o investimento em capital humano. Anteriormente, vimos que o retorno do investimento em capital humano só é tributado no futuro, quando a renda do indivíduo aumenta em função dos anos dedicados aos estudos, o que implicaria uma vantagem tributária em relação ao investimento em capital financeiro, por exemplo. Contudo, se a renda normal da poupança é isenta, o desequilíbrio se inverte sensivelmente, ainda mais quando a renda do trabalho permanece submetida à tributação progressiva. Nesse caso, a opção de estudar em vez de trabalhar e poupar no presente levará o indivíduo a provavelmente pagar uma alíquota marginal mais elevada no futuro, quando sua renda for maior. Talvez o resultado líquido e a valor presente do fluxo de renda seja inferior ao do indivíduo que não estudou, mas trabalhou desde cedo e poupou, permanecendo isento nos rendimentos da poupança e submetido a uma alíquota mais baixa sobre seu salário.

Desse modo, Mirrlees et al. (2011, p. 31) reconhecem que existem alguns bons motivos - "bem fundamentados na teoria econômica" - para se desviar do primeiro tipo de neutralidade almejada por um modelo ótimo, introduzindo alguma distorção na dimensão intemporal das decisões de consumo, trabalho e poupança para oferecer os estímulos adequados em um mundo real e não ideal, em que as preferências, habilidades e restrições dos indivíduos são muito

(18) Outra hipótese em que a tributação da poupança seria ótima, conforme Mirrlees et al. (2011, p. 30), ocorreria em caso de uma relação complementar entre o lazer hoje e o consumo futuro: "In principle, consumption of goods or services that are complements to leisure should be taxed more heavily so as to increase work incentives. But a similar argument will hold when we consider consumption today and consumption tomorrow. (...) By acting as a tax on future consumption, taxing savings may increase the incentive to work if consumption tomorrow is complementary to leisure today." 
heterogêneas. Mas nas conclusões a Revisão evita, "por cautela", sugerir alguma recomendação prática nessa direção.

All of these arguments are well founded in economic theory. They justify levying some tax on the normal return to capital, though not necessarily at full labour income tax rates, as in a comprehensive income tax. However, there are several reasons to be cautious in applying these arguments immediately to policy.

Duas razões principais são levantadas para essa cautela: a necessidade de estudos quantitativos mais acurados sobre os potenciais benefícios e custos de se tributar em alguma dose o rendimento normal da poupança e a pretensa dificuldade de se fazer isso sem afetar a segunda e mais importante neutralidade almejada pelos modelos ótimos, aquela que diz respeito à escolha dos ativos no qual investir. De fato, como veremos na seção seguinte, a necessidade de equalizar o tratamento tributário dispensado às várias alternativas de investimento (reduzindo não só a eventual vantagem de aplicar o capital em títulos públicos como da empresa de se endividar para abater os juros do lucro tributável) é um dos grandes desafios que os modelos tradicionais de tributação da renda têm enfrentado, mas isso não implica necessariamente adotar o princípio da isenção do rendimento normal.

Existem diferentes visões sobre qual melhor caminho seguir, e os países mais desenvolvidos têm preferido até hoje enfrentar os problemas advindos da crescente mobilidade e opacidade do capital com mudanças marginais em seus sistemas de tributação. Nos últimos 10 anos, por exemplo, a maioria dos países da OCDE reduziu a tributação do lucro nas empresas e aumentou a tributação dos dividendos distribuídos a acionistas, mas o modelo de tributação da renda e dos lucros permaneceu basicamente o mesmo. Isso não significa que esse cenário não possa mudar radicalmente e que os Estados Unidos, sob liderança dos conservadores, não possam iniciar um processo que venha revolucionar o atual modelo de tributação no mundo, substituindo o atual método de apuração do imposto de renda por uma variante da apuração pelo valor adicionado e forçando as demais nações a seguirem a mesma direção. A crescente desigualdade social e o movimento em favor de uma maior tributação do capital em nível internacional, entretanto, atuam em sentido contrário, explicitando que - no fundo - as feições do sistema tributário são determinadas em última instância pela tensão permanente de interesses e ideologias e apenas secundariamente pelos modelos teóricos.

\section{Da teoria à prática: o que a experiência internacional revela?}

As distorções advindas da adoção do modelo clássico de tributação da renda, como a oneração do prêmio inflacionário embutido no rendimento do capital, a dupla tributação dos lucros (vis a vis a tributação única e mais rebaixada dos ativos financeiros) e o estímulo ao adiamento da realização dos ganhos de capital (o chamado efeito lock-in) vem sendo enfrentadas nas últimas décadas de modo muito diverso pelos países, sugerindo que até hoje não existe um consenso sobre qual o melhor caminho a seguir, nem modelos que sirvam para todas as realidades. Ainda na década de 70, as grandes nações europeias (Alemanha, França e Reino Unido) começaram a introduzir alíquotas diferenciadas (split rates) para os dividendos ou sistemas de imputação e de crédito, que visavam integrar a tributação dos lucros na pessoa 
jurídica e na pessoa física, eliminando total ou parcialmente a dupla tributação e o diferencial de carga tributária em relação às demais rendas de capital.

Contudo, esses mecanismos eram adotados em países em que as alíquotas marginais máximas do imposto de renda das pessoas físicas eram invariavelmente bem superiores às alíquotas do imposto de renda das pessoas jurídicas. Desse modo, os recebedores de dividendos dos estratos superiores de renda sempre teriam um adicional de imposto a pagar.

Em 1981, quando a base de dados tributários da OCDE tem início, nove países do grupo (incluindo Austrália, Nova Zelândia e Canadá, além dos europeus) registravam sistemas de imputação ou alíquotas diferenciadas, e a alíquota máxima média aplicável aos dividendos era de $63 \%$ nas pessoas físicas (compondo uma carga tributária de $75 \%$ quando considerado o imposto recolhido também pelas empresas). Ao longo das décadas de 80 e 90, entretanto, as proposições dos economistas supply-side e dos políticos conservadores influenciaram para que houvesse reduções substanciais no grau de progressividade do imposto de renda e no nível de tributação das rendas do capital, ao mesmo tempo em que novas estratégias para lidar com o problema da dupla tributação dos lucros passaram a ser testadas.

O modelo de flat tax, por exemplo, um imposto de renda simplificado, com apenas uma alíquota, que acabou sendo adotado por diversos países do Leste Europeu e ex-repúblicas soviéticas nas duas últimas décadas, tem origem numa proposta formulada em 1981 por dois economistas americanos, Robert Hall e Alvin Rabushka. Inicialmente, a proposta foi lançada em uma página editorial do Wall Street Journal e popularizada com a ideia de que, se aprovada, a declaração de imposto de renda seria tão simples que caberia num cartão postal.

Apenas em 1983 os dois economistas traduziram sua ideia para um artigo acadêmico, nos quais na verdade propunham adotar uma espécie de imposto sobre valor adicionado (com dedução do gasto com folha de salários) para substituir o imposto de renda tradicional, algo similar ao que hoje defendem alguns neoclássicos e líderes republicanos. ${ }^{19} \mathrm{~A}$ versão popularesca, entretanto, é que se tornou famosa e levou seus autores e patrocinadores (como os institutos Hoover e Cato) a promoverem em 2007 uma espécie de comemoração de "bodas de prata", como eles próprios a definiram.

Na publicação comemorativa, Rabushka (2007) rememora com entusiasmo como a ideia de flat tax teria influenciado a reforma tributária de 1986 da administração Reagan, na qual um sistema de múltiplas alíquotas (com uma máxima de 50\%) foi substituído por outro de duas alíquotas (15\% e $28 \%$ ), e lamenta os retrocessos posteriores nos governos Bush e Clinton.

When control of Congress passed into Republican hands in 1995, House majority leader Dick Armey put the flat tax back into the limelight. Armey, Steve Forbes, and other political leaders talked up the flat tax during the next few years, but it never came to the floor of the House or Senate for a vote. Ideas, however, have a way of cropping up again

${ }^{19}$ Ver Hall e Rabushka $(1983,1995)$. 
in unexpected places. Against the advice of Western economists, the newly independent country of Estonia enacted a flat tax effective January 1, 1994. It set the rate at 26 percent to balance its budget. It has since lowered the rate on several occasions, and the tax is scheduled to fall to 20 percent in 2009. Estonia has also abolished its corporate income tax, only imposing the same flat rate on distributed dividends.

Do mesmo modo que a Estônia, diversos países do antigo bloco soviético (das vizinhas Letônia e Lituânia ao longínquo Quirguistão, passando pela própria Rússia) também adotaram variantes da proposta de flat tax nos anos e na década seguintes. A primeira onda de flat tax se circunscreveu aos países do Mar Báltico, mas a segunda, iniciada pela Rússia em 2001, se expandiu pelo Leste Europeu e pela Ásia, chegando a países como Iraque, Mongólia e Kuwait. Ao todo, em 2007 contabilizavam-se pelo menos 17 países com algum tipo de flat tax em vigor, mas nenhum grande país desenvolvido aderiu a essa "revolução"20.

O movimento maciço de países que gravitaram em torno da União Soviética em direção a um modelo tributário que não faz distinção do nível de renda é interpretado por alguns economistas libertários (Mittchell, 2007, p. 10-12) como reflexo de um amadurecimento político das populações que sofreram com o comunismo, uma vez que a defesa da "tributação dos mais ricos" (ou seja, a progressividade tributária) é vista como retórica de luta de classes e não como um princípio caro às próprias democracias anglo-saxãs:

Most of the new flat tax nations are former Soviet republics or former Soviet bloc nations, perhaps because people who suffered under communism are less susceptible to classwarfare rhetoric about taxing the rich...

For much of the 20th century, policymakers subscribed to the notion that the tax code should be used to penalize those who contribute most to economic growth. Raising revenue was also a factor, to be sure, but many politicians seem to have been more motivated by the ideological impulse that rich people should be penalized with higher tax rates. If nothing else, the growing community of flat tax nations shows that class-warfare objections can be overcome.

É claro que o componente ideológico não pode ser desprezado, mas os economistas do Fundo Monetário Internacional oferecem uma explicação mais pragmática e convincente para essa onda de flat tax: tratar-se-ia de uma estratégia dos governos desses novos países capitalistas de sinalizar uma "mudança de regime" por meio de uma agenda de reformas prómercado (Keen et al., 2006, p. 35):

The implementation of the flat tax followed a fundamental change in government, starting with the formation of a markedly pro-liberalization government in Estonia in 1992 and continuing through the election of Vladimir Putin in 2000, the 2003 'Rose Revolution' in Georgia, and the 2004 coalition government in Romania. These were governments with a strong mandate for reform, inheriting an environment in which traditions of tax compliance and enforcement were weak, and in which the income tax, while being levied

(20) A rigor, a ilha de Jersey e Hong Kong são considerados os países pioneiros na adoção de um flat tax, ainda na década de 40 . 
at rates commonplace in OECD economies and elsewhere, raised - and continues to raise - relatively little revenue.

Não podemos deixar de lembrar, ademais, que parte da nova classe de milionários dos ex-países socialistas é formada por antigos integrantes ou descendentes da burocracia estatal, que se aproveitaram do próprio processo de privatização das empresas nacionais e concentraram muita riqueza nas últimas duas décadas, como mostra Piketty (2013). Desse modo, é natural que as reformas no sistema de tributação tenham também sido influenciadas pelos interesses dessa elite empresarial e política. O próprio estudo mencionado do FMI avalia que o entusiasmo gerado pelo flat tax se deve mais ao fato de as reformas terem implicado redução da carga tributária para os mais ricos do que pelo aspecto da uniformização de alíquotas ou dos seus atributos quanto à neutralidade.

As reais motivações por trás da flat tax ficam evidentes, por exemplo, nas críticas que os economistas do Instituto Cato fazem às tentativas da OCDE e da Comissão Europeia de impor limites à competição tributária (Mittchell, 2007, p.12):

Although the flat tax revolution has been impressive, there are still significant hurdles. Most important, international bureaucracies are obstacles to tax reform, both because they are ideologically opposed to the flat tax and because they represent the interests of high-tax nations that want tax harmonization rather than tax competition...

Fortunately, these efforts to create a global tax cartel have largely been thwarted, and an 'OPEC for politicians' is still just a gleam in the eyes of French and German politicians. That means that tax competition is still flourishing, and that means that the flat tax club is likely to get larger rather than smaller.

Em resumo, as palavras dos defensores mais fervorosos do flat tax sugerem fortemente que seu objetivo principal não é simplificar ou eliminar distorções, mas exacerbar a competição tributária para erradicar qualquer forma de tributação do capital. Líder na onda de isenção de dividendos, por exemplo, a Estônia aparentemente obteve sucesso econômico com a fórmula, mas às custas de maior desigualdade social ${ }^{21}$.

Na prática, apenas outros três países com flat tax replicaram o exemplo da Estônia e suprimiram a dupla tributação dos lucros, isentando os dividendos ao nível das pessoas físicas (Letônia, República Eslováquia e Romênia) ${ }^{22}$. Mas dois deles voltaram atrás parcialmente nos últimos anos: a Letônia, que reintroduziu em 2010 uma taxação de 10\% sobre os dividendos distribuídos a não-residentes, e a Eslováquia, que em 2011 criou uma contribuição social sobre dividendos e em 2017 substituiu-a pelo imposto de renda normal, com uma alíquota de 7\% (ou $35 \%$ para residentes de paraísos fiscais) ${ }^{23}$.

(21) O índice de Gini da Estônia (0,36) é um dos maiores entre os países europeus que integram a OCDE.

(22) Os demais países, como a Rússia, não deixaram de tributar os lucros duplamente, apesar do sistema flat que adotaram.

(23) A Letônia chegou a instituir em 1997 a isenção dos rendimentos das aplicações financeiras conjuntamente com os dividendos. A medida pode parecer à primeira vista lógica, mas em realidade cria uma distorção contra o investimento produtivo, cuja rentabilidade é tributada pelo imposto de renda da empresa. Recentemente essa isenção foi abolida, e os ganhos com juros são taxados em $10 \%$. 
Em ambos os casos, da Letônia e da Eslováquia, a tributação dos dividendos distribuídos a acionistas se soma à tributação original do lucro na empresa, que é de $15 \%$, totalizando uma carga tributária sobre os lucros bastante inferior à média da OCDE, que ainda hoje supera os $40 \%$. Na Estônia e na Romênia, por sua vez, o lucro permanece sendo tributado em apenas uma etapa, com uma taxação total de respectivamente $20 \%$ e $16 \%$, igual à aplicada aos demais rendimentos do capital e do trabalho.

Além desses países do Leste Europeu, é interessante referir o caso da Grécia e do México, que integram a OCDE e, embora nunca tenham instituído um flat tax, conviveram durante algum tempo com a isenção de dividendos ao nível das pessoas físicas. O México adotou em 1990 um sistema que isentava os lucros distribuídos, mas desde 2014 voltou a tributá-los com uma alíquota de $10 \%$, cumulativa ao imposto corporativo de $30 \%$. Já a Grécia aboliu a isenção de dividendos ainda em 2009 e hoje complementa o imposto de $29 \%$ sobre o lucro das empresas com uma taxação de $10 \%$ sobre os valores distribuídos às pessoas físicas. Por fim, o Brasil instituiu a isenção de dividendos em 1996, mas as tributações das diversas formas de renda do capital permaneceram desalinhadas entre si e em relação às rendas do trabalho, problema este que se agravou com os regimes especiais de tributação das micro e pequenas empresas, como será visto à frente.

Em resumo, tanto a isenção de dividendos quanto o flat tax parecem ter perdido fôlego como alternativas para lidar com os problemas que afligem o modelo clássico de tributação da renda. Nos países mais desenvolvidos, há algum tempo as atenções tem sido mais canalizadas para outros dois modelos teóricos que já foram implementados na prática e sobre os quais nos debruçaremos agora: um deles é o modelo dual nórdico, o outro é o novo modelo belga de allowance for corporate equity (ACE), que se assemelha ao juro sobre capital próprio (JCP) do Brasil.

Originalmente proposto por Devereaux e Freeman (1991), o ACE é um mecanismo de ajuste no cálculo do imposto de renda das empresas que visa isentar de tributação o rendimento normal do capital, definido como o rendimento equivalente àquele que seria obtido pelos acionistas com a aplicação de seu capital em um ativo financeiro sem risco. Note-se que a isenção se aplica apenas ao imposto devido pela empresa e que o lucro distribuído aos sócios deve ser tributado exatamente como qualquer outra forma de renda do capital, de modo que a tributação não interfira na escolha do investidor onde aplicar seu dinheiro.

Além de proporcionar neutralidade na alocação do capital entre distintos ativos, essa fórmula também torna neutra a decisão da empresa de como financiar seus investimentos, com capital próprio ou endividamento. No modelo clássico, é mais vantajoso para a empresa se endividar do que se capitalizar, pois os juros pagos pelo empréstimo são abatidos do cálculo do imposto de renda. Mas essa vantagem desaparece se o rendimento normal (ou juros) sobre o capital próprio também puder ser deduzido, como previsto pelo ACE.

O primeiro país a adotar esse mecanismo foi a Croácia, em 1994, sendo logo seguida pelo Brasil (1996), Itália (1997) e Áustria (2000) e, mais recentemente, pela Bélgica (2006). Contudo, atualmente, apenas o Brasil e a Bélgica mantêm o mecanismo de dedução ativo. Todos os demais países aboliram sua implementação após poucos anos de experiência, como explica Klemm (2006). 
É importante assinalar ainda que apenas a Croácia e a Bélgica adotaram o modelo puro de ACE, isentando completamente o rendimento normal do capital. A Itália e a Áustria usaram esse dispositivo apenas para aplicar uma alíquota mais baixa sobre os rendimentos normais e exclusivamente para as novas capitalizações. No Brasil, o JCP se restringe os montantes efetivamente distribuídos aos acionistas (não se aplica aos lucros retidos) e é calculado a partir de uma taxa de juros mais baixa do que a de mercado, a TJLP. Contudo, considerando que os financiamentos obtidos no Brasil pelas grandes empresas junto aos bancos oficiais são lastreados na TJLP e que essa taxa supera, em geral, a corrosão inflacionária, o mecanismo atende parcialmente ao objetivo da neutralidade ${ }^{24}$.

Note-se que a parcela de lucro distribuída sob a forma de JCP é tributada na pessoa física em 15\%, que é a mesma alíquota aplicável aos rendimentos das aplicações financeiras e ganhos de capital. Com isso, o estímulo para a empresa se financiar com empréstimo e não capitalização é menor. Porém, esse mecanismo foi implementado no Brasil juntamente com a isenção de dividendos, criando uma combinação inusitada e que apresenta os seguintes resultados práticos:

1. Se o lucro da empresa é retido, ele não se beneficia do JCP e da isenção oferecida à distribuição, resultando em uma tributação de $34 \%$ na empresa e mais $15 \%$ no momento de realização do ganho de capital (assumindo que o lucro retido se refletirá na valorização das ações).

2. Se o lucro é distribuído, a parcela correspondente ao rendimento do JCP será isenta na pessoa jurídica e tributada em $15 \%$ na pessoa física, e a parcela excedente será tributada apenas na pessoa jurídica em $34 \%$, resultando numa alíquota média entre $15 \%$ e $34 \%$ (mediana de 23,5\% segundo Torres, 2017).

3. Se a empresa estiver enquadrada no regime de lucro presumido, por sua vez, a tributação efetiva será na maioria das vezes inferior aos $15 \%$ porque as alíquotas do imposto de renda são aplicadas sobre um porcentual presumido do faturamento que teoricamente equivaleria ao lucro, mas na prática fica comumente bem abaixo do lucro verdadeiro (no setor de serviços, por exemplo, alíquota efetiva é de 7,68\% sobre faturamento).

Ou seja, o modelo de tributação dos lucros do Brasil não é neutro em relação às decisões da empresa de como financiar seus investimentos, por capitalização e empréstimo de um lado ou retenção de lucros por outro. Há um claro viés contra a retenção de lucros e a favor da capitalização.

Além disso, esse modelo estimula a chamada "pejotização", ou seja, transfiguração de renda do trabalho em renda do capital, em função do diferencial de carga tributária. Com todos os custos tributários e não-tributários embutidos no negócio, um profissional liberal que preste serviço como pessoa jurídica (no Simples ou lucro presumido) geralmente paga uma alíquota efetiva inferior àquela que estaria submetido como pessoa física (até $27,5 \%$, segundo tabela progressiva do IRPF).

(24) Há países como Israel, por exemplo, que adotam uma dedução do lucro tributável baseada apenas na taxa de inflação (Klemm, 2006). A Bélgica, por sua vez, passou a limitar a dedução apenas aos novos investimentos. 
Alguns conglomerados empresariais também fazem uso desses regimes especiais para pagar menos imposto de renda, organizando suas coligadas de tal forma que as receitas sejam transferidas para aquelas enquadradas no "lucro presumido" e os custos para as que estão no "lucro real". Sem falar nas modalidades de aplicação financeira, como os fundos e letras de crédito imobiliários, que estão isentos de pagamento de qualquer imposto, enquanto outras rendas do capital semelhantes (aluguéis) também se submetem ao IRPF progressivo.

Trata-se, portanto, de um sistema de tributação da renda desalinhado, gerador de distorções nas decisões dos agentes econômicos, e que, além disso, possibilita que os muito ricos, que vivem de renda do capital e tem maior acesso às técnicas de planejamento tributário (e sucessório), sejam tributadas, em média, bem abaixo dos padrões internacionais vigentes nas economias desenvolvidas, que varia de $40 \%$ a $60 \%$. Fato este que contribui para a acentuada concentração de renda e riqueza no topo da pirâmide social brasileira, como demonstrado por estudos como Morgan (2017) e Gobetti e Orair (2017).

Diante disso, é oportuno refletir se as experiências e paradigmas nos quais o sistema tributário brasileiro se baseou são os mais adequados ou se, alternativamente, não dever-se-ia mirar outras tendências mais influentes entre as nações mais desenvolvidas do mundo. Entre essas tendências, destaca-se o modelo dual de tributação da renda, que foi introduzido entre os anos 80 e 90 nos países nórdicos e consiste basicamente em submeter todas as rendas do capital a uma alíquota flat reduzida, enquanto mantém as rendas do trabalho sendo tributadas progressivamente. A principal justificativa para isso, como visto, é oferecer uma compensação pelo fato de o rendimento do capital ser tributado em valor nominal e não real (descontando a inflação) e de o lucro, em particular, já ter sido tributado ao nível da empresa.

No modelo dual puro, a alíquota sobre a renda do capital deve ser alinhada à alíquota da primeira faixa do imposto sobre a renda do trabalho e, somada com a alíquota incidente sobre o lucro da empresa, deve se aproximar da alíquota máxima da tabela progressiva das pessoas físicas. Em geral, é assim que os países nórdicos fazem (ver Tabela 1), fixando a alíquota sobre as rendas do capital (PIT) no mesmo patamar que a alíquota do imposto corporativo (CIT) para integrar mais facilmente a tributação da pessoa jurídica com a da pessoa física.

Tabela 1

Modelo dual nórdico de imposto sobre rendas (alíquotas em \%)

\begin{tabular}{|c|c|c|c|c|c|}
\hline \multirow{2}{*}{\multicolumn{2}{|c|}{ País/Ano de instituição }} & Dinamarca & Suécia & Noruega & Finlândia \\
\hline & & 1987 & 1991 & 1992 & 1993 \\
\hline \multirow{5}{*}{ 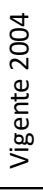 } & Imposto corporativo (CIT) & 30 & 28 & 28 & 29 \\
\hline & Imposto pessoal (PIT) & & & & \\
\hline & Dividendos & $28 / 43$ & 30 & 0 & 0 \\
\hline & Outras rendas do capital & $28 / 43$ & 30 & 28 & 29 \\
\hline & Renda do trabalho & $38-59$ & $31-56$ & $28-48$ & $29-53$ \\
\hline \multirow{5}{*}{ 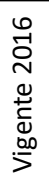 } & Imposto corporativo (CIT) & 22 & 22 & 25 & 20 \\
\hline & Imposto pessoal (PIT) & & & & \\
\hline & Dividendos & $27 / 42$ & 30 & $0 / 28,75$ & $0 / 25,5$ \\
\hline & Outras rendas do capital & $27 / 42$ & 30 & 25 & 30 \\
\hline & Renda do trabalho & $36-56$ & $29-60$ & $25-38,7$ & $23-54$ \\
\hline
\end{tabular}

Fonte: Eggert e Geiser (2005); OCDE (2004, 2016); Deloitte (2016). 
Contudo, nem todos os países nórdicos adotaram sistemas de integração, concedendo aos acionistas crédito pelo imposto já pago pelas empresas, como é o caso da Suécia, que até hoje tributa duplamente o lucro, na pessoa jurídica e na física. A única diferença é que, ao adotar o modelo dual, a Suécia passou a tributar os dividendos distribuídos com uma alíquota flat e não mais progressivamente (como, aliás, era o que ocorria no Brasil até 1995), o que por si só já proporcionou um alívio tributário em comparação ao passado.

A Noruega que, por outro lado, introduziu o sistema dual em 1992, foi o país nórdico que desde o princípio garantiu um tratamento mais favorável para os dividendos, fixando as alíquotas sobre as rendas do capital e sobre a renda corporativa em $28 \%$ cada e adotando um mecanismo de completa imputação (ou compensação) do imposto pago pela empresa. Assim, o imposto corporativo funcionava como se fosse uma antecipação, um imposto de renda retido na fonte sobre os dividendos distribuídos, não havendo mais nada a ser recolhido pelas pessoas físicas.

Na prática, esse mecanismo equivalia a isentar os dividendos distribuídos, como ocorre no Brasil, o que criava um forte estímulo para - no caso de pequenas empresas - transfigurar renda do trabalho (tributada em até $48 \%$ ) em renda do capital (tributada em apenas 28\%). Em 2006, porém, a Noruega substituiu o sistema de imputação por uma dedução equivalente ao rendimento normal do capital (rate-of-return allowance, $R R A$ ), calculado aplicando-se uma taxa de juros notacional sobre o valor das ações. Desse modo, os dividendos (e os ganhos de capital) continuariam isentos somente na medida em que não ultrapassassem esse limite. Acima dele, o lucro voltaria a ser duplamente tributado.

Esse método de dividir o lucro entre a parcela normal e a excedente também resolveu ou amenizou o problema da transfiguração de renda do trabalho em renda do capital nas pequenas empresas. A parcela normal passou a ser tratada como remuneração do capital do proprietário (ou acionista) e permanece sendo tributada apenas na empresa em $28 \%$, enquanto a parcela excedente é considerada a remuneração pelo seu trabalho e ficará sujeita a uma alíquota adicional de $28 \%$, calibrada para, quando somada aos $28 \%$ também recolhidos pela empresa, coincidir com a alíquota máxima do imposto de renda aplicável às rendas do trabalho $[28 \%+28 \% \times(1-28 \%)=48,1 \%]$. Assim, boa parte do estímulo para transfigurar renda do trabalho em renda do capital desaparece.

A Finlândia inicialmente também adotou um mecanismo de compensação completa do imposto sobre o lucro recolhido pela empresa no momento de calcular o imposto de renda pessoal (equivalente a uma isenção de dividendos distribuídos), mas em 2005 substituiu esse sistema por um método ad hoc, teoricamente mais simples que o norueguês: $70 \%$ dos lucros voltaram a ser tributados uma segunda vez na pessoa física e $30 \%$ permaneceram isentos.

Na prática, a regra do $70 \%$ x 30\%, substituída em 2015 por $85 \%$ x $15 \%$, para definir quanto dos dividendos distribuídos serão isentos e quanto serão tributados na pessoa física equivale a uma alíquota sobre os dividendos menor do que a aplicada sobre as demais rendas do capital $(85 \%$ x $30 \%=25,5 \%)$ para compensar o fato de que o lucro já ter sido tributado na 
empresa em 20\%. Em média, a carga tributária sobre os lucros chega a aproximadamente $40 \%$ $[20 \%+25,5 \% \times(1-20 \%)=40,4 \%]$, patamar que tem sido mantido estável desde 2005, embora com mudanças importantes de composição, uma vez que a Finlândia e outros países têm reduzido a alíquota do imposto corporativo (CIT) e aumentado a alíquota efetiva do imposto de renda pessoal (PIT) sobre os dividendos distribuídos.

É importante observar, porém, que essa regra mais simples de tributação dos lucros vale apenas para empresas com cotas, nas quais não há um problema sério com a transfiguração da renda do trabalho em renda do capital. Nas pequenas empresas, sem cotas, a Finlândia adota uma versão mais complicada, que também faz uso de uma taxa de retorno (a exemplo da Noruega) para definir o que é renda do capital e quanto dela é isenta ou não. Todo lucro que represente uma rentabilidade inferior a $8 \%$ ao ano é considerado renda do capital, e $75 \%$ dela estará isenta do imposto sobre dividendos (30\%) desde que não ultrapasse os EU 150 mil anuais, o que equivale a uma alíquota média de 7,5\% sobre esse montante. Acima dos EU 150 mil anuais e abaixo da rentabilidade de $8 \%$, os dividendos são tributados com uma alíquota sobre a renda do capital mais elevada, de $34 \%$, aplicada apenas sobre a parcela de $85 \%$, o que equivale a uma alíquota média de $28,9 \%$.

Por fim, a parcela do lucro que eventualmente supere os $8 \%$ de rentabilidade anual é também dividida em duas partes: $25 \%$ é isenta (da mesma forma que os EU 150 mil do lucro normal) e $75 \%$ é tributada como se fosse renda do trabalho, ou seja, sujeita a alíquotas progressivas de até 54\% (maior, portanto, do que os 34\% aplicáveis às rendas do capital).

Na prática, essas múltiplas partições da renda e a faixa de isenção transformam o imposto de renda sobre os dividendos das pequenas empresas em um imposto progressivo e não mais flat, como originalmente concebido. Mas essa progressividade é justificada porque parte do dividendo é, na verdade, renda do trabalho ou lucro extraordinário, em cujo caso não há porque adotar um tratamento especial, como a isenção parcial ou total.

A Dinamarca, por sinal, é o país nórdico que desde o início manteve um maior grau de progressividade na tributação dos dividendos distribuídos, flexibilizando a estrutura flat do modelo dual. Embora a proposta original do governo dinamarquês, em 1985, fosse introduzir uma alíquota única reduzida para as rendas do capital, a reforma aprovada pelo Congresso para vigorar em 1987 manteve a progressividade, mas com alíquotas máximas menores do que as aplicáveis às rendas do trabalho, que na época chegavam a $68 \%$.

Posteriormente, a Dinamarca adotou duas alíquotas para a tributação das rendas do capital: uma mais baixa, atualmente em $27 \%$, e outra mais alta, de $42 \%$. A renda com juros também é tributada progressivamente, com uma carga tributária que varia de $36 \%$ a $42 \%$.

Ou seja, comparativamente aos demais países nórdicos, a Dinamarca ainda é o que tributa mais pesadamente a renda, tanto do capital quanto do trabalho. Em compensação, é o único país da região que não adotou um imposto sobre a riqueza líquida como fizeram Noruega, Finlândia e Suécia. 
O imposto sobre o patrimônio fez parte do modelo dual original, porque funcionaria como uma compensação pela redução na tributação dos fluxos de renda. Recentemente, entretanto, Finlândia e Suécia aboliram esse tributo, e apenas a Noruega permanece com ele, o que guarda coerência com o modelo norueguês, uma vez que é o único que isenta completamente o retorno normal do capital embutido nos dividendos distribuídos.

Fazendo uma graduação de carga tributária total sobre os dividendos, a Noruega aparece com a menor (entre $28 \%$ e $48 \%$, dependendo do quanto o lucro eventualmente se distancie do rendimento normal), seguida pela Finlândia (40,4\%), pela Suécia $(51 \%)$ e pela Dinamarca (entre $43 \%$ e $54 \%$, dependendo do valor absoluto distribuído, independentemente da rentabilidade, que pode ficar abaixo ou acima do normal). Portanto, o modelo dual se distingue em forma e conteúdo nos países nórdicos, não sendo possível encontrar uma clara tendência em favor de um outro protótipo específico.

Em termos teóricos, o modelo norueguês (assim como o belga, que se utiliza do ACE para isentar o rendimento normal do capital) se aproxima mais do defendido por Mirrlees et al. (2011), enquanto os modelos dinamarquês e finlandês talvez se enquadrem mais na concepção de Piketty, Saez e Zucman (2013) e Banks e Diamond (2008), respectivamente, por preservarem um maior grau de progressividade no tratamento das rendas do capital.

$\mathrm{Na}$ prática, os principais países europeus abandonaram (ou estão abandonando) os sistemas de imputação e incorporaram elementos do modelo dual (sem usar esse nome) ao tributar a renda do capital com uma ou no máximo duas alíquotas "rebaixadas", que em geral equivalem a algo próximo da metade da alíquota máxima aplicável às rendas do trabalho. Alemanha, Itália, Suíça e Áustria, por exemplo, estão adotando uma alíquota flat em moldes muito similares ao da Suécia ou Finlândia, enquanto Espanha, Portugal, Irlanda e Reino Unido seguem utilizando mais do que uma alíquota (e uma estrutura progressiva), como faz a Dinamarca.

Em média, esses países europeus impõem uma tributação sobre os lucros, quando consideramos também o imposto pago pelas empresas, ao redor de $45 \%$, que é também hoje a alíquota máxima da tabela progressiva do imposto de renda da maioria. Ou seja, uma carga tributária intermediária entre a Noruega/Finlândia e Suécia/Dinamarca.

Já a França é hoje um dos poucos países que mantém um sistema de tributação da renda mais próximo ao conceito de comprehensive income tax, tributando os rendimentos do capital conjuntamente com os do trabalho, mas com uma dedução de $40 \%$ para os dividendos. Austrália, Canadá e Nova Zelândia também continuam utilizando esse modelo amplo, mas com o método de imputação (completo ou quase completo), no qual o imposto sobre o lucro da empresa vira crédito para a pessoa física na hora de calcular seu imposto de renda, resultando em uma carga tributária total similar à incidente sobre a renda do trabalho, em torno de $50 \%$ (exceto Nova Zelândia, em que é de 33\%).

Diferenças à parte, os dados da OCDE indicam uma tendência recente dos países reduzirem a tributação do lucro na empresa, ao mesmo tempo em que ampliam a tributação efetiva dos dividendos distribuídos, de modo a manter a carga tributária mais ou menos estável. 
Isso tem ocorrido tanto entre os nórdicos, quanto entre os do Leste Europeu e os da Europa Ocidental e parece ser, antes de mais nada, uma decorrência da competição tributária, já que o imposto corporativo estimula a realocação territorial das corporações, enquanto o imposto sobre dividendos geralmente só afeta os residentes.

Dos 34 países da OCDE, metade fez um movimento nessa direção entre 2008 e 2015. Aparentemente, essa mudança pode parecer neutra, mas uma análise mais acurada mostra que não. Em primeiro lugar porque um acionista estrangeiro pode ser afetado pela alíquota sobre o lucro da empresa, mas em geral não é atingido pela tributação sobre pessoas físicas fora do seu domicílio. Em segundo lugar, porque a tributação das pessoas físicas (diferente das pessoas jurídicas) pode ser progressiva. Em terceiro lugar, porque a incidência do imposto sobre o lucro da empresa pode ser transferida para os trabalhadores da empresa ou para os consumidores, diferente do imposto sobre os dividendos distribuídos, que é totalmente pessoal (Altshuler et al., 2010).

Qual o impacto dessa mudança sobre a distribuição de renda? O primeiro fator pode afetar simultaneamente a dimensão internacional e doméstica da distribuição de renda, uma vez que pode envolver menos tributos pagos por estrangeiros e mais por residentes do país, mas tende a ser neutro se todos os países agirem do mesmo modo. O segundo fator reduzirá a desigualdade se a tributação da renda do capital for progressiva, enquanto o terceiro fator também terá algum impacto sobre a desigualdade se assumirmos que ao menos uma parte da incidência tributária será transferida dos trabalhadores/consumidores para os acionistas. ${ }^{25}$

Além desse impacto distributivo positivo, a mudança no mix no estágio de tributação do lucro eventualmente pode contribuir para o crescimento econômico, seja a partir de um referencial keynesiano (via efeito multiplicador pelo aumento da renda dos mais pobres), seja a partir de um referencial neoclássico como o adotado por Johansson et al. (2008). Estes autores criam um ranking de tributos de acordo com seu efeito sobre o crescimento e concluem que os impostos sobre a renda são a princípio piores do que os impostos sobre o consumo, mas reconhecem que a troca da tributação da renda pela do consumo pode reduzir a progressividade e aumentar a desigualdade, seja pelo efeito sobre os preços, seja pelo alívio tributário para as rendas mais elevadas. Por isso, sugerem como alternativa melhorar o design de cada fonte de tributação, ampliando a base de tributação do consumo, reduzindo o imposto corporativo (mais pernicioso entre todos no ranking) e aumentando o imposto pessoal sobre dividendos e outras rendas do capital.

Nesse contexto, a literatura empírica - tanto Johansson et al. (2008), quanto Altshuler et al. (2010) - parece validar uma reforma no desenho da tributação da renda e dos lucros que passe por menos imposto sobre as empresas e mais sobre as pessoas, de acordo com seu nível

(25) Altshuler et al. (2010) assumem, em seu modelo, que as taxas mais altas sobre ganhos de capital e dividendos são absorvidas pelos acionistas, que estão mais concentrados no topo da distribuição do que recebedores de outras rendas do capital. Além disso, estudos empíricos utilizados pelos autores indicam que parte do imposto corporativo é transferido para a conta dos trabalhadores. 
Tributação do capital: teoria e prática (e o caso brasileiro)

de renda. Movimentos desse tipo - o contrário, por sinal, do que o Brasil fez nos últimos 20 anos - podem contribuir para melhorar simultaneamente a eficiência econômica e a distribuição de renda, desafiando o clássico trade-off da teoria ótima.

\section{Considerações finais}

$\mathrm{O}$ artigo buscou contribuir com o debate atual em torno de uma agenda de reforma tributária mais progressiva a partir de uma análise do processo de revisão das teorias e dos modelos de tributação da renda e dos lucros adotados nas últimas décadas em diferentes partes do mundo. Do ponto de vista teórico, hoje existem dúvidas e divergências consideráveis no seio do mainstream sobre o que seria "ótimo" em matéria de tributação. Muitos economistas neoclássicos têm criticado o irrealismo dos fundamentos por trás de enunciados que outrora foram muito populares nos círculos acadêmicos, como o de que a progressividade e a tributação do capital seriam ineficientes do ponto de vista econômico e do bem estar social.

Nas palavras de Banks e Diamond (2008), o debate na atualidade não é se a renda do capital deve ou não ser tributada, mas como deve ser. Enquanto um grupo talvez majoritário, representado pela revisão de Mirrlees, defende a ideia de isentar o "rendimento normal" do capital para reduzir as distorções sobre as decisões de investimento, mas reconhece que podem existir outras boas razões para tributá-lo parcialmente, a geração de Piketty e Saez (mas também Stiglitz) tem defendido a necessidade de alcançar as altíssimas rendas, o que só pode ser feito com a oneração do capital e de forma progressiva, tanto por razões distributivas quanto por questão de eficiência, já que a natureza da concentração de riqueza atual compromete a própria meritocracia e produtividade. Ambos os lados levantam questões pertinentes para o debate, que devem ser avaliadas com ponderação.

Por outro lado, a experiência internacional tem revelado distintas estratégias nacionais para enfrentar os problemas derivados do modelo clássico de tributação da renda, que vão do flat tax no Leste Europeu ao modelo dual nos países nórdicos, passando por sistemas de dedução ou imputação que visam eliminar ou amenizar a dupla tributação dos lucros. Esses modelos conviveram durante os últimos 20 anos, sem uma clara tendência hegemônica e várias deserções, como no caso dos países que abandonaram sistemas parecidos com o do juros sobre capital próprio brasileiro (Croácia, Itália e Áustria) e dos que deixaram de isentar dividendos (Grécia, México e Eslováquia).

Mais recentemente, entretanto, duas tendências dos países mais desenvolvidos merecem destaque: uma é a incorporação de elementos do modelo dual, com tributação linear ou quase linear da renda do capital, e outra é a redução das alíquotas incidentes sobre o lucro das empresas e compensação com maior tributação das rendas de capital das pessoas físicas. Mudanças que tem sido tratadas na literatura empírica como positivas tanto para a distribuição de renda quanto para o crescimento.

Diante disso, é necessário repensar o modelo brasileiro de tributação da renda do capital e suas particularidades, como a isenção de dividendos distribuídos e o mecanismo de 
JCP. O fato é que nem a almejada neutralidade foi alcançada com essas medidas, como mostra o desalinhamento da tributação das distintas rendas de capital, nem o país se beneficiou de um surto de investimentos estimulado pela desoneração do capital, mas nossa concentração de renda no topo se consolidou como uma das mais altas do planeta. Isso indica tanto que políticas tributárias pró-capital não são necessariamente eficientes, quanto que a política distributiva não pode se basear apenas no gasto público.

No contexto de acentuada concentração de renda verificado no país, uma reforma tributária que amplie a progressividade, alcançando as altas rendas do capital, poderia ter impactos positivos para o desenvolvimento econômico - segundo os novos modelos de tributação ótima - e contribuir para um ajuste fiscal mais equilibrado, que não tenha tantos efeitos multiplicadores negativos, como é o caso de medidas que reduzam o gasto público social e promovam contração de investimento público.

A implementação de mudanças tributárias nessa direção, conforme mostra Piketty (2014), enfrenta historicamente resistências das elites econômicas. Nesse sentido, a migração para um modelo dual de tributação da renda mais próximo aos dos países nórdicos, mantendo algum grau de isenção dos dividendos distribuídos (referenciado na rentabilidade ou na magnitude), pode ser uma alternativa viável diante do conflito distributivo verificado no Brasil. $^{26}$

Além de permitir alcançar de alguma forma as altas rendas, via tributação de dividendos distribuídos, o modelo nórdico poderia proporcionar maior equidade de tratamento tributário entre as distintas formas de renda e, em particular, entre as rendas do capital. Na prática, por exemplo, seria possível reduzir a tributação do lucro na empresa e elevar a tributação sobre rendimentos financeiros (bem como a supressão de isenções vigentes para algumas aplicações, como os fundos imobiliários), o que pode - por ambos canais - estimular o investimento privado, principalmente via lucros retidos.

Como ficou demonstrado, a atual isenção de dividendos distribuídos a pessoas físicas, conjugado com o mecanismo de JCP, penaliza a retenção de lucros, principalmente na vigência de alíquotas mais elevadas de tributação na empresa. Em situações de crise, principalmente, acentua a tendência de entesouramento de lucros pelas pessoas físicas (isentos na distribuição) e sua canalização para ativos mais líquidos, seguros e rentáveis, como são os títulos públicos no Brasil.

Dessa forma, é possível promover uma reforma na tributação das rendas do capital que concilie os princípios da equidade e neutralidade, com efeitos positivos para o crescimento econômico. E essa reforma pode ser implementada de modo que seu efeito líquido sobre a carga tributária seja neutro - ou no curto prazo, ou no médio prazo - conforme as medidas

(26) Outro modelo mais recente, que pode servir de referência ao Brasil, é o adotado pelo Chile recentemente. Trata-se de um modelo no qual os dividendos (e todas as rendas) são tributados conjuntamente e de forma progressiva, e no qual o imposto sobre o lucro retido ao nível da empresa (incluindo o IRPJ) pode ser abatido na declaração anual. 
Tributação do capital: teoria e prática (e o caso brasileiro)

sejam graduadas no tempo e se neutralizem em termos de efeito sobre a arrecadação e atividade econômica.

\section{Referências bibliográficas}

ALMEIDA, A. F.; PAES, N. L. The influence of interest on net equity and interest rates on taxneutrality - a case study of the Brazilian corporate taxation. EconomiA, v. 14, p. 185-198, 2013.

ALTSHULER, R.; HARRIS, B. H.; TODER, E. Capital income taxation and progressivity in a global economy. Virginia Tax Review, v. 30, p. 355, 2010.

ATKINSON, A. The Mirrlees Review and the state of public economics. Journal of Economic Literature, v. 50, n. 3, p. 770-780, 2012.

ATKINSON, A.; STIGLITZ, J. E. The design of tax structure: direct versus indirect taxation. Journal of Public Economics, v. 6, n. 1-2, p. 55-75, 1976.

ATKINSON, A.; PIKETTY, T.; SAEZ, E. Top incomes in the long run of history. Cambridge: NBER, Oct. 2009. (Working Paper, n. 15408).

BANKS, J.; DIAMOND, P. The base for direct taxation. Prepared for the Report of a Commission on Reforming the Tax System for the 21st Century. London: The Institute for Fiscal Studies (IFS), 2008.

CHAMLEY, C. Optimal taxation of capital income in general equilibrium with infinite lives. Econometrica, v. 54, n. 3, p. 607-622, 1986.

COY, P. An immodest proposal: a global tax on the superrich. Bloomberg, April 10, 2014. Available at: https://www.bloomberg.com/news/articles/2014-04-10/thomas-pikettys-globaltax-on-capital-may-not-be-a-crazy-idea.

DELOITTE. Taxation and investment 2016: reach, relevance and reliability (Norway, Finland, Sweden ae Denmark). Available at: https://dits.deloitte.com.

DEVEREAUX, M.; FREEMAN, H. A general neutral profits tax. Fiscal Studies, v. 12, n. 3, p. 1-15, Aug. 1991.

DIAMOND, P.; SAEZ, E. The case for a progressive tax: from basic research to policy recommendations. Journal of Economic Perspectives, v. 25, n. 4, p. 165-190, 2011.

EGGERT; WOLFGANG; GENSER, BERND. Dual income taxation in EU member countries. CESifo DICE Report, v. 3, n. 1, p. 41-47, 2005. Disponível em: http://www.cesifogroup.de/portal/pls/portal/docs/1/1193560.PDF.

GOBETTI, S. W.; ORAIR, R. O. Taxation and distribution of income in Brazil: new evidence from personal income tax data. Brazilian Journal of Political Economy, v. 37, n. 2 (147), p. 267-286, Apr./Jun. 2017. 
Sérgio Wulff Gobetti

HALL, R.; RABUSHKA, A. Low tax, simple tax, flat tax. New York: McGraw Hill, 1983.

HALL, R.; RABUSHKA, A. The flat tax. Stanford: Hoover Institution Press, 1995.

JOHANSSON, A.; HEADY, C.; ARNOLD, J.; BRYS, B.; VARTIA, L. Taxation and economic growth. OCDE, Economics Department, 2008. (Working Paper, n. 620).

JUDD, K. L. Redistributive taxation in a simple perfect foresight model. Journal of Public Economics, v. 28, n. 1, p. 59-83, 1985.

KALDOR, N. An expenditure tax. London: Allen and Unwin, 1955.

KAPLOW, L. The theory of taxation and public economics. New Jersey: Princeton University Press, 2008.

KEEN, M.; KIM, Y.; VARSANO, R. The “flat tax(es) ": principles and evidence. Washington: FMI, 2006. (IMF Working Paper, n. 218).

KLEMM, A. Allowances for corporate equity in practice. Washington: FMI, 2006. (IMF Working Paper, n. 259).

LUCAS, R. Supply-side economics: an analytical review. Oxford Economic Papers, v. 42, n. 2, p. 293-316, 1990.

MEDEIROS, M.; SOUZA, Pedro Herculano; CASTRO, Fábio Ávila. A estabilidade da desigualdade de renda no Brasil, 2006 a 2012: estimativa com dados do imposto de renda e pesquisas domiciliares. Ciência e Saúde Coletiva, Rio de Janeiro, v. 20, n. 4, abr. 2015.

MILL, J. S. Principles of political economy J. W. Ashley, ed., 1921. London: Longmans, 1849.

MIRRLEES, J. A. An exploration in the theory of optimal income taxation. Review of Economic Studies, v. 38, p. 175-208, 1971.

MIRRLEES, J. et al. Tax by design: the Mirrlees Review. Oxford University Press, 2011. 548p.

MITTCHELL, D. The global flat tax revolution. Washington: Cato Institute, Jul./Aug. 2007. (Cato Policy Report). Available at: https://www.cato.org/policy-report/julyaugust2007/global-flat-tax-revolution.

MORGAN, M. Extreme and persistent inequality: new evidence for Brazil combining national accounts, surveys and fiscal data, 2001-2015. WID. World Working Paper Series, n. 2017/12.

MUSGRAVE, R. A. Progressive taxation, equity, and tax design. In: SLEMROD (Org.). Tax progressivity and income inequality. Cambridge University Press, 1994.

NIELSEN, S. B.; SORENSEN, P. B. On the optimality of the Nordic system of dual income taxation. Journal of Public Economics, v. 63, p. 311-329, 1997.

ORGANIZAÇÃO PARA COOPERAÇÃO E DESENVOLVIMENTO ECONÔMICO (OCDE). OECD Tax Database. Corporate and Capital Income Taxes, 2004 e 2016. Available at: http://www.oecd.org/tax/tax-policy/tax-database.htm. 
Tributação do capital: teoria e prática (e o caso brasileiro)

PIKETTY, T. O capital no século XXI. Rio de Janeiro: Intrínseca, 2014.

PIKETTY, T.; SAEZ, E. Income inequality in the United States, 1913-1998. Quarterly Journal of Economics, v. 118, n. 1, p. 1-39, 2003.

PIKETTY, T.; SAEZ, E. A theory of optimal capital taxation. Cambridge: NBER, Apr. 2012. (NBER Working Paper, n. 17989).

PIKETTY, T.; SAEZ, E.; ZUCMAN, G. Rethinking capital and wealth taxation. Mimeo, 2013. Available at: http://piketty.pse.ens.fr/files/PikettySaez2014RKT.Pdf.

RABUSHKA, A. The flat tax's Silver anniversary. In: HALL, R.; RABUSHKA, A. The Flat Tax. Hoover Institute. 2007. Available at: http://www.hoover.org/research/flat-tax.

SHEFFRIN, S. M. Perceptions of fairness in the crucible of tax policy. In: SLEMROD (Org.). Tax progressivity and income inequality. Cambridge University Press, 1994.

SMITH, A. [1776]. A Riqueza das Nações. São Paulo: Editora Nova Cultural, 1996.

SORENSEN, P. B. Dual income taxes: a Nordic tax system. Paper prepared for the Conference on New Zealand Tax Reform - Where to Next? Wellington: Victoria University, Feb. 2009.

STIGLITZ, J. The great divide: unequal societies and what we can do about them. New York: WW Norton, 2015.

STIGLITZ, J. Pareto efficient taxation and expenditures: pre-and re-distribution. Cambridge: NBER, 2017. (Working Paper, n. 23892).

TORRES, F. Dois impostos e duas medidas: a discrepância de reação. Valor Econômico, p. C10, 27 jul. 2017. 